\title{
QPRT wt Allele
}

National Cancer Institute

\section{Source}

National Cancer Institute. QPRT wt Allele. NCI Thesaurus. Code C112838.

Human QPRT wild-type allele is located in the vicinity of $16 \mathrm{p} 11.2$ and is approximately 20

$\mathrm{kb}$ in length. This allele, which encodes nicotinate-nucleotide pyrophosphorylase

[carboxylating] protein, plays a role in NAD biosynthesis. 